KEYWORDS

Education

Income

Income distribution

Wages

Equality

Labour market

Ethnicity

Social classes

Peru

Adolfo Figueroa

Centrum Business School

Catholic University of Peru

$\multimap$ afiguer@pucp.edu.pe
CEPAL REVIEW 102 DECEMBER 2010

\section{Is education}

\section{income-equalizing? \\ Evidence from Peru}

\author{
Adolfo Figueroa
}

I

the education system income-equalizing? The evidence from developing countries shows that while education has expanded tremendously in recent decades, income distribution has not become more equal. This article seeks to resolve this seeming paradox. A theoretical model is constructed for the relationship between education and income in which ethnicity plays a key role in the distribution process. The model predicts that the education system is not income-equalizing. A broader set of predictions are derived from the theoretical model and then compared to Peruvian data. Statistical tests produce results that are consistent with the model's predictions. 


\section{I}

\section{Introduction}

Education has expanded tremendously in developing countries in recent decades. World Bank data show that the net primary school enrolment rate rose from $78 \%$ to $89 \%$ between 1980 and 1997, while the secondary school rate went up from $53 \%$ to $63 \%$ (World Bank, 2001, table 6, p. 285). Yet, paradoxically, the degree of income inequality has not declined (Deininger and Squire, 1996, table 5; Li, Squire and Zou, 1998). Why is education not an income-equalizing system?

The literature has not provided a satisfactory scientific explanation for this paradox; and the most popular theoretical models on intergenerational mobility (Becker and Tomes, 1979; Durlauf, 1996) have not been subjected to statistical testing in a developing-country setting.

In contrast, the empirical literature on the relationship between education and income inequality in the developing world is vast but lacks theoretical underpinnings. In the particular case of Latin America, compared to the situation in more advanced countries, three empirical insights can be gleaned: (i) the distribution of education, measured in terms of years of schooling, is more unequal; (ii) the quality gap between schools attended by rich and poor students is greater; and (iii) income differentials between workers with high and low education levels are much wider, which some authors attribute to the relatively limited supply of educated workers (Bourguignon,
Ferreira and Menendez, 2007; Birdsall, De la Torre and Menezes, 2008; Blom and Vélez, 2004).

This article explores the role of class and ethnicity in explaining the observed relationships between education and income, including the paradox. A simple theoretical model is developed for that purpose, and its predictions are tested against Peruvian data. The role of ethnicity in the relationship between education and incomes in developing countries is not widely discussed in the international literature. For Peru, Nopo, Saavedra and Torero (2004) found that ethnicity played an important role in the statistical breakdown of urban wage differences. For Brazil, the study by Bourguignon, Ferreira and Menéndez (2007) cited above also found that race affected earnings differentials. Neither study has theoretical underpinnings, however.

The article is organized as follows. Section II presents a theoretical model in which class and ethnicity play a significant role in the education process. Section III discusses the role of initial inequality in family asset endowments in the process of human capital accumulation. The static and dynamic models are presented in sections IV and V. In section VI, the model's empirical predictions are tested statistically against Peruvian data, utilizing parametric and nonparametric tests (described in full in the Appendix). Section VII presents the conclusions.

\section{II}

\section{A simple theoretical model}

Consider a hypothetical capitalist society in which the distribution of economic and social assets among individuals is highly unequal. Individuals are assumed to participate in the economic process endowed not only with economic assets but also with social ones, thus introducing social factors into the economic process. Social assets are special goods, for they belong to the realm of rights and entitlements granted to individuals in a society. They are not physical goods, nor are they marketable.

In this study, social assets will basically refer to political and cultural assets. The former are defined as the capacity of individuals to exercise individual and collective rights, including the right to have rights. Unequal individual endowments of political assets generate a hierarchy of citizens in society-first-class 
and second-class. As a result, not all individuals are equal before the law; moreover, not all individuals have the same degree of access to the public goods supplied by the State. ${ }^{1}$

Cultural assets are defined as the right of social groups to exercise cultural diversity in a multicultural and multi-ethnic society. Unequal endowments of cultural rights generate ethnic groups with a hierarchy of ethnic markers in society: first- and second-class races, languages, religions and customs. These markers are referred to as cultural because their hierarchies are socially constructed and they are transmitted from generation to generation. Inequality in cultural assets leads to social practices of segregation, exclusion and discrimination against certain ethnic groups.

Unequal individual endowments of political and cultural assets are assumed to be highly correlated in society, so political assets alone can be included in the theory. For simplicity, this fictitious society can be referred to as the "sigma society".

The unequal distribution of economic and political assets is one of the features of the sigma society. The other feature concerns factor endowments, which implies the existence of overpopulation. The marginal productivity of the whole labour force is too low for wage rates to clear labour markets.

In order to derive empirically refutable predictions from sigma theory, a specific sigma society, or a particular model of sigma theory, must now be constructed. A set of auxiliary assumptions are then introduced.

Race, class and citizenship constitute the social structure of sigma society. The total population can be divided into: (i) two social classes: capitalists and workers; (ii) two types of citizens: first-class and second-class; (iii) three ethnic groups: the Blues, the Reds and the Purples, the latter resulting from interbreeding between the other two races. ${ }^{2}$

\footnotetext{
1 The concept of citizenship used in this study corresponds to that proposed by the sociologist T.H. Marshall in his classic 1950 essay: "Citizenship is a status bestowed on those who are full members of a community. All who possess the status are equal with respect to the rights and duties with which the status is endowed" (Marshall and Bottomore, 1992, p. 18).

${ }^{2}$ In a paper that analyses theoretical relationships between consumer preferences and culture, Akerlof and Kranton (2000) construct an abstract world of two ethnic groups, the Greens and Reds, in which the Greens are the dominant group. To use primary colours, call them Blues and Reds here; then introduce a third ethnic group: the Purples, resulting from miscegenation between the two races. As in that paper, it is assumed here that people cannot choose their ethnic identity, which is exogenous.
}

Table 1 shows the social structure of sigma in matrix form. The Blues constitute the capitalist class, owning most physical capital. The Purples and Reds belong to the working class. Purples are endowed with skilled labour and Reds with unskilled labour only. In terms of citizenship endowments, the Blues and the Purples are first-class citizens, while the Reds are second-class, thus forming the initial inequality in individual asset endowments. The social matrix shows a society that is highly correlated in terms of asset endowment. Three social groups are thus identifiable; for easy reference and for reasons that will become apparent later on, they will be called by the letters A, Y and Z.

Sigma society can now be distinguished analytically from a socially homogeneous capitalist society, which could be referred to as "epsilon society". If epsilon society were represented by table 1 , there would still be two social classes (capitalists and workers) but only one citizenship class (C). There would still be three ethnic groups, but only one level of citizenship for all (C). In epsilon society, therefore, racial differences would become unimportant and the social matrix would collapse into two social groups only, $\mathrm{A}$ (capitalists) and $\mathrm{Y}$ (workers); social group $\mathrm{Z}$ would not exist. While sigma society is intended to resemble the developing world, epsilon society corresponds to the first world.

The question considered by this paper is whether or not the process of human capital accumulation through education can reduce inequality in the initial distribution of assets (naturally including human capital) and thus make income flows less unequal. The answer is developed in the rest of the paper.

TABLE 1

\section{Social structure of sigma society: race, class and citizenship}

\begin{tabular}{lcccc}
\hline $\begin{array}{l}\text { Ethnic } \\
\text { group }\end{array}$ & $\begin{array}{c}\text { Physical } \\
\text { capital }\end{array}$ & $\begin{array}{c}\text { Human } \\
\text { capital }\end{array}$ & Citizenship & $\begin{array}{c}\text { Social } \\
\text { group }\end{array}$ \\
\hline Blues & $\mathrm{K}_{\mathrm{b}}$ & $\mathrm{K}_{\mathrm{h} 1}$ & $\mathrm{C}_{1}$ & $\mathrm{~A}$ \\
Purples & 0 & $\mathrm{~K}_{\mathrm{h} 1}$ & $\mathrm{C}_{1}$ & $\mathrm{Y}$ \\
Reds & 0 & $\mathrm{~K}_{\mathrm{h} 0}$ & $\mathrm{C}_{0}$ & $\mathrm{Z}$ \\
\hline
\end{tabular}

Source: prepared by the author.

Symbols: $\mathrm{K}_{\mathrm{b}}$ physical capital endowment; $\mathrm{K}_{\mathrm{h} 1}$ high-level human capital endowment; $\mathrm{K}_{\mathrm{h} 0}$ low-level human capital endowment; $\mathrm{C}_{1}$ first-class citizenship endowment; $\mathrm{C}_{0}$ second-class citizenship endowment. 


\section{III}

\section{Human capital accumulation: the role of initial endowments}

Human capital is usually defined as the stock of knowledge and productive skills embodied in workers. As individuals do not acquire this stock at birth, they need to invest in acquiring it through the education process.

The initial conditions that each individual brings to the educational system at each level are essential for learning. In the literature of related sciences (psychology, biology and neuroscience), the standard view is that initial talent endowments matter, and talents are multiple - the so-called "multiple intelligence theory" (Gardner, 1999).

Brain plasticity theory is another important component of the standard view. While the individual's initial talent endowments - his or her genetic inheritance - are exogenous (nature), talents become endogenous over time because brain development also depends on the social environment (nurture) and on the interaction between the two. Brain plasticity theory is usually stated as follows: "The brain is not a computer that simply executes predetermined programs. Nor is it a passive gray cabbage, victim to the environmental influences that bear upon it. Genes and environment interact to continually change the brain, from the time we are conceived until the moment we die" (Ratey, 2002, p. 17).

On aggregate, individual endowments of talents, genetically-based gifts, can be assumed to be normally distributed among the population (the result of a random mechanism). The distribution of learning skills, in contrast, will be generated by the social environment. The important distinction made by Rousseau (1755) refers precisely to these two factors. He identified two types of inequalities among individuals: the natural, determined by randomly assigned natural endowments; and the artificial, determined by the functioning of society.

The sigma model will assume that nutrition, health and language are the main channels through which wealthy families can develop higher levels of learning skills in their children as compared to poorer families. Personal access to nutrition and health, as either private or public goods, is assumed to be differentiated by social group.
Language is another factor of cognitive skill inequality associated with a family's socio-economic level. There are language differences between individuals, which in sigma society lead to language inequality. This inequality is seen in various aspects of language use in the dominant tongue in society, such as vocabulary, syntax, ways of speaking, and reading and writing skills. Sociolinguistic theory views language inequality as mostly due to personal experiences (the social environment) rather than genetic factors (Hudson, 1996, p. 204).

Inequalities in language skills between social groups imply unequal cognitive skills among their children. Abstract and complex thoughts are not just language-dependent, but complex languagedependent. As philosopher John Searle has stated: "Some thoughts are of such complexity that it would be empirically impossible to think them without being in possession of symbols. Mathematical thoughts, for example, require a system of symbols... Complex abstract thoughts require words and symbols" (Searle, 1995, p. 64). The implication seems to be that written language allows the individual to work with more abstract and complex thoughts than does oral language alone.

Consider a situation in which the $\mathrm{Y}$ workers live in a written culture and most of them are literate, but the $\mathrm{Z}$ workers live in an oral social environment, most of them are illiterate in the dominant language, and their aboriginal language is not a written one. Assume further that $Z$ workers live in an oral culture in segregated communities. In a setting of this type, language skills in the dominant language will be very unequally distributed through society.

Due to their illiteracy, $\mathrm{Z}$ populations will be limited in the use of abstract and complex thoughts. To be illiterate in a written culture is different from being illiterate in an oral culture. The handicap will be greater in the former. $\mathrm{Z}$ populations will then show lower levels of language skills in the dominant language, and thus their children will display lower cognitive skill levels than the children of the A and Y populations. 
The characteristic of multicultural, multilingual and hierarchical society makes sigma a heteroglossic society. This term comes from sociolinguistic theory and refers to the existence of various forms of, or variations in, the use of the dominant language, with a hierarchy separating those who are socially superior (with a good grasp of the dominant language) from those considered inferior.

The sigma model then assumes that language inequality plays a crucial role in generating unequal cognitive skills. Sociolinguistic theory goes even further: "Linguistic inequality can be seen as a cause of social inequality, but also as a consequence of it, because language is one of the most important means by which social inequality is perpetuated from generation to generation" (Hudson, 1996, p. 205).

To conclude, in a sigma society with pronounced initial inequality in economic and political asset endowments, and given the random distribution of talents in the population, people will start the human capital accumulation process endowed with unequal cognitive or learning skills. This initial inequality plays a major role in the process of human capital accumulation among social groups. It should be noted that this proposition is not empirically refutable or falsifiable, because learning capacity is unobservable. It will therefore be used as a primary assumption of the theory of human capital accumulation, presented below.

\section{IV}

\section{The transformation of education into income: a static model}

The static sigma model can be represented by the following system of equations:

$$
\begin{gathered}
k_{h}=f(E, X), f 1>0, f_{2}>0, X=Z, Y, A \\
y=g\left(k_{h}, X, p\right), g_{1}>0, g_{2}>0, g_{3}>0
\end{gathered}
$$

Hence,

$$
\begin{aligned}
& y=g(f(E, X), X, p) \\
& =G(E, X, p), G_{1}>0, G_{2}>0, G_{3}>0
\end{aligned}
$$

Equation (1) states that the average human capital endowment of individuals $\left(k_{h}\right)$ depends upon their average education level measured as years of schooling $(E)$ and the social group to which they belong $(Z, Y$, $A)$. For a given social group, an exogenous increase in the average education level will result in a higher average human capital level; for a given education level, the average human capital level will be higher for individuals belonging to the higher-ranked social groups (where the hierarchy in ascending order is Z, Y, A).

Equation (2) says that the average income of individuals $(y)$ depends upon their average endowments of human capital and the social group to which they belong, for given market conditions (p). In a given social group, the higher the average human capital endowment, the higher the average income will be; for a given endowment of human capital, average income will be higher for individuals belonging to higher-ranked social groups (Z, Y, A, in ascending order).

To simplify, assume that market conditions depend on the international terms of trade $(p)$, which are the sole exogenous variable determining the aggregate level of output, employment and mean income in the short run. A higher $p$ means a higher relative price for exported goods compared to imports, which in turn implies higher labour productivity and higher demand for labour by domestic firms. Thus, for given educational levels, the higher the value of $p$, the higher the average income of the social groups.

Sigma theory assumes that the social structure stems from the initial inequality in the distribution of economic and political assets. This inequality, the variable $\delta$ (delta), underlies the $X$ term in equation (3). So income differences between social groups depend upon differences in their average education levels and asset endowments. As long as the values of the exogenous variables $E$ and $\delta$ remain constant, average income in each social group will remain constant, and so will the income distribution across social groups. 
Figure 1 depicts the static model. Points $m, n$ and $r$ are the average values of years of schooling in the three social groups $\mathrm{A}, \mathrm{Y}$ and $\mathrm{Z}$, and points $m$ ', $n$ ' and $r$ ' are the corresponding average incomes. The initial inequality in the distribution of assets gives rise to a situation in which the capitalist class has the most years of schooling, human capital and income, followed by the other two social groups; moreover, additional years of schooling in group $\mathrm{Z}$ will result in a higher income level along curve $Z$. The same process applies to group $\mathrm{Y}$ and group A. The equilibrium situation is represented by curve $\mathrm{L}$, which is empirically observable.

Under the equilibrium situation shown in figure 1, three cases can be considered to analyse the effect of exogenous changes in education on income inequality. Firstly, an additional year of education in group $\mathrm{Z}$ alone will increase the mean income of that group and reduce the initial inequality; but the effect will be small. Secondly, an additional year of schooling in all social groups will have a small effect on inequality; certainly, average income will rise in all groups, but it is not clear that relative incomes would change substantially. Thirdly, additional years of schooling in all three groups, with more years in group Z, will have an ambiguous effect or (at best) a small one.

FIGURE 1
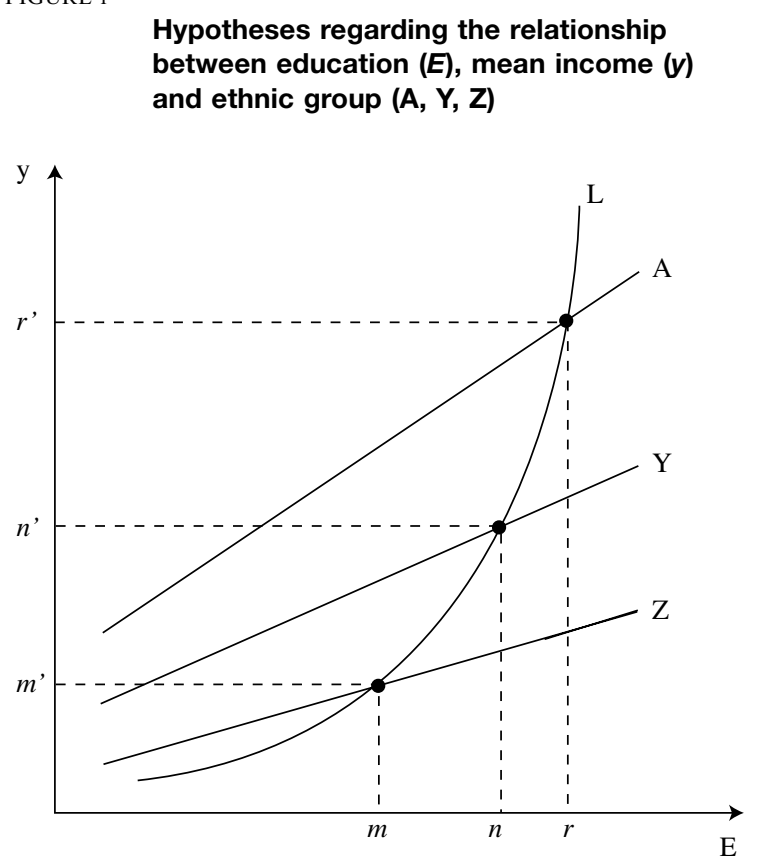

Source: prepared by the author.
In short, the static model predicts that a reduction of inequality in years of schooling will not imply a significant reduction in income inequality; moreover, the same number of schooling years does not generate the same average income for all social groups. The reason is that the difference in years of schooling is only one of the factors generating income differentials between social groups.

The conclusion would be different if the relationship between years of schooling and incomes were not separable; that is, if just one curve existed for all groups. If the three curves were reduced to curve A in figure 1, an additional year of schooling would raise income by the same amount in all three social groups. Then, if differences in years of schooling were reduced, income inequality would decrease as well; moreover, the same number of years of schooling would generate the same average income for all social groups. But according to the sigma model, this is not how the capitalist system operates. Sigma society has three separate curves (class and race relationships), while epsilon society would only have two separate curves (class relationships).

The relationships presented in figure 1 refer to the average values of the variables for each social group. Successful individual cases may occur (people jumping from curve $\mathrm{Z}$ to $\mathrm{Y}$ or even to $\mathrm{A}$ ), but the theory predicts that such cases will be the exception rather than the rule.

Changes in the exogenous variables will change the average incomes of social groups in specific ways, as indicated by the sign of their effects in equation (3). The model's empirical predictions are thus represented in equation (3), which is empirically refutable and can be used to test the model's validity statistically. The L curve in figure 1 relates the average values of years of schooling and income for each social group. The static equilibrium situation shown in figure 1 is thus represented by the $\mathrm{L}$ curve.

The sigma model departs from the standard analysis in several ways. Standard empirical studies usually measure the relationship between education and income along line L. Under the sigma model, however, the L curve cannot be used to compare the effect of exogenous changes in years of schooling on incomes, or rates of return on education (as is done incorrectly in the international literature), because the effect of education on income operates along different paths (lines A, Y, Z) for different social groups. Measuring the relationship along the $\mathrm{L}$ curve would certainly overestimate the effect of education on income. 
It should also be noted that this model refers to group analysis, in which the aim is to explain differences in income and education across social groups. By contrast, in the standard literature the empirical relationship between income and education is studied using Mincerian earnings regressions (Mincer, 1974), which refer to individual analysis and thus seek to study differences in income and education between individuals (including regression variables such as experience, age, gender and other individual characteristics).

\section{A dynamic model}

Assume now that the quantity of education is determined endogenously in society and in each social group in the long run. Assume also the initial conditions of the economic process are given; in other words, individual endowments of economic and political assets are unequal at the outset, and these determine the social structure A, Y and Z. Likewise, ignore the short-run effects of the international terms of trade in this long-run model.

Dynamic equilibrium will now be defined as a sequence of static equilibrium situations over time. Therefore, the static equilibrium situation will now be considered as the solution of the initial period or generation, which is given by the $\mathrm{L}$ curve in figure 1 . This curve shows the initial values of education and income for each social group, implying mean education and income values for society in the aggregate.

The dynamic model assumes that part of the total output produced in this period or generation will be allocated to human capital investment in the form of years of schooling. This investment is financed by families and by the State through fiscal policies, depending on the social group. As a result, there will be more education and human capital for the second period, because the average income in society increases. For simplicity, the model assumes that the growth of average income depends essentially upon the growth of human capital and hence also on the expansion of education. The other factors usually considered as affecting economic growth, such as physical capital accumulation and technological change, are assumed to be induced by higher levels of education.

Now consider the dynamic process by social group. In the next period or generation, education levels and average income will be higher in each social group (and on aggregate); there will be new investment, resulting in even higher education levels and average incomes for each social group (and for society as a whole) in the subsequent period, and so on. This dynamic process can be modelled through the L curve in figure 1. Given the initial equilibrium, the investment in education will imply an outward shift of the curve, say, to L1, which will in turn imply a new equilibrium with higher income for each social group. Further investment in education will take place in this period and the curve will shift outward again, to L2 say, and so on. In sum, the L curve will shift outward endogenously over time.

In the process of accumulating human capital through education, each social group will move along its specific path, given by lines Z, Y and A in figure 1. It was shown above that the process of education expansion along their corresponding paths does not generate significant reductions in income inequality between social groups. Differences in years of schooling can be reduced, but not income differences. Given the initial inequality in asset endowments, there are two reasons why incomes do not converge: (i) in the transformation of education into human capital, more equality in years of schooling does not imply more equality in human capital, since social groups accumulate human capital along different paths; (ii) in the transformation of human capital into incomes, the latter depend on access to basic markets, which is differentiated by social group, and this relationship is not altered by human capital accumulation alone. This means that education is transformed into income along different paths, depending on the social group. The relative incomes of the three social groups over time are path-dependent. In other words, the initial conditions of society matter; social history counts.

Initial inequality in economic and political asset endowments is thus the key to explaining the nonequalizing nature of the education system. Differences in years of schooling may eventually be eliminated, because there is a ceiling to years of education; but 
this does not significantly reduce income inequality, for social groups move along different paths over time. Educational mobility is possible, but socio-economic mobility is much more problematic.

In intergenerational terms, the dynamic sigma model predicts that the "children" of a given social group will tend to inherit the economic status of their "parents". Long ago, the British biologist Francis Galton established the "law of regression towards the mean" (equalizing tendency) in relation to height differences between children and their biological parents. The sigma model presented here predicts that there will be "no regression towards the mean" in incomes between "children" and "parents" in the same social group.
The dynamic sigma model can explain the paradox as follows: developing countries are socially heterogeneous and hierarchical societies, i.e., they resemble sigma society. Inequality in the initial distribution of economic and political assets makes the society operate with exclusions; in particular, the processes of transforming education into human capital and this into incomes are differentiated by class and ethnicity relationships. In developed countries, the initial inequality is such that these processes are differentiated by class relations alone; but in the developing world, ethnicity also plays a significant role in the reproduction of inequality. As long as the initial inequality in asset endowments remains unchanged, the education system will not be income-equalizing.

\section{VI}

\section{Empirical hypotheses tested against Peruvian data}

A set of empirical predictions about the relationships between education and income can be derived from the static sigma model. These predictions will then be tested against data from Peru, a multi-ethnic and multicultural society, to see whether they confirm or refute the model. The data set comes from the National Household Survey (ENAHO) of 2003.

Empirical estimation of the size of ethnic groups is a complex task. In the case of Peru, the $\mathrm{Z}$ population corresponds to the descendants of indigenous populations. Up to four criteria were considered to measure the size of such groups, all of which have disadvantages:

- The mother tongue criterion: this criterion reduces ethnicity to the language marker, thereby underestimating its size. Indigenous people who do not speak an aboriginal language - either because they belong to a group that does not have a legacy of an aboriginal language or belong to a generation that has lost the aboriginal languagewould formally not be counted as indigenous.

- The self-identification criterion: this measure understates the size of indigenous populations because individuals tend to conceal their ethnicity in a hierarchical society.

- The rural residence criterion: this also underestimates the size of the indigenous population because people migrating to the cities would not be counted as indigenous.

- The rural district birthplace criterion: this criterion again understates the size of the indigenous population because children born in a large city (following migration) would not be counted as indigenous.

This study chose the last of these to estimate the size of the indigenous population, since it seems to be the most reliable. Moreover, the analysis will refer to the adult population only, aged 25 or over; so people born in the rural districts of Peru in the three natural regions (the coast, the Andes and the Amazon), irrespective of where they currently live, are considered mostly indigenous. This represents the $\mathrm{Z}$ social group of the theoretical model.

People born in the most affluent residential districts of Lima, regardless of where they now reside, are considered to belong mostly to the A social group. The mestizo or Y group was calculated by the difference between the two. The estimates are as follows: social group A accounts for $3.5 \%$ of the total adult population, group $\mathrm{Y}$ for $27.5 \%$ and group $\mathrm{Z}$ for $69 \% .^{3}$

\footnotetext{
3 The 2001 Household National Survey (ENAHO) contained a question on ethnic self-identification. The result was that
} 


\section{H1. Hypothesis of quantitative differences in years of schooling between social groups}

As shown in figure 1, the static sigma model predicts that the average number of years of schooling varies by social group, increasing in the order Z, Y, A. This relationship is shown in table 2. Mean years of schooling vary between social groups: 14 years for group A, 11 years for group $Y$ and 7 for group $Z$. The medians show the same ranking: 14,11 and 5 years. Parametric and non-parametric statistical tests (see Appendix) show that the observed differences in mean values are statistically significant. The empirical data do not refute the hypothesis, but reveal pronounced inequalities in education.

Using education levels (basic, secondary, technical and university) instead of years of schooling also reveals major inequalities. Nearly $70 \%$ of group A have attained post-secondary education, compared

among family heads, $43 \%$ declared themselves to be indigenous descendants, while $34 \%$ claimed to speak an aboriginal language (Hall and Patrinos, 2006, tables 2.1, 2.7 and 7.1). These estimates of the proportions of indigenous people are clearly smaller than the $69 \%$ calculated in this study, as would be expected from the definitions used. Given the order of magnitude of these estimates, the claim made by many Peruvian writers that the predominant ethnic group is Y ("we are a mestizo country") is not empirically supported. to $36 \%$ of group Y and just $15 \%$ of group Z; the national average is $21 \%$. The exclusion of group $Z$ from post-secondary education is remarkable.

Few studies have been carried out on the conversion of education into human capital, by social group. Those that do exist have compared test scores, for a given grade, between two categories of schools: private-public and urban-rural. The results show that the average level of knowledge, measured by test scores, is higher among students attending private schools than those in public schools, and also higher in urban schools than rural ones (Rivera, 1979; Cueto, Jacoby and Pollit, 1997; Peru, Ministry of Education, 2005).

There is also some evidence of the negative role of malnutrition in the learning process at school. A study carried out as part of the Joint Programme on Latin American Economic Integration (ECIEL) shows a large and statistically significant negative correlation between school performance and degree of malnutrition, based on a sample of the student population in Lima and in urban and rural Puno (Rivera, 1979).

As social group $\mathrm{Z}$ is predominant in rural areas, it follows that the transformation of education into human capital in Peru seems to operate as shown in the structural equation (1). These results are consistent with the hypothesis. After 180 years as a republic,

TABLE 2

Peru: education level by social group, 2003

(Thousands of people and percentages)

\begin{tabular}{|c|c|c|c|c|c|c|c|c|}
\hline \multirow{3}{*}{ Education level } & \multicolumn{6}{|c|}{ Social group } & \multirow{2}{*}{\multicolumn{2}{|c|}{ Total }} \\
\hline & \multicolumn{2}{|c|}{$\mathrm{Z}$} & \multicolumn{2}{|c|}{$\mathrm{Y}$} & \multicolumn{2}{|r|}{ A } & & \\
\hline & $\mathrm{N}^{\mathrm{a}}$ & (percentage) & $\mathrm{N}$ & (percentage) & $\mathrm{N}$ & (percentage) & $\mathrm{N}$ & (percentage) \\
\hline None & 1283 & 14.1 & $110^{\mathrm{b}}$ & 3.3 & $0.7^{\mathrm{b}}$ & 0.2 & 1394 & 10.9 \\
\hline Basic & 3903 & 43 & 556 & 16.5 & $10.1^{b}$ & 2.8 & 4470 & 34.9 \\
\hline Secondary & 2611 & 28.7 & 1475 & 43.8 & 94.9 & 26.9 & 4180 & 32.6 \\
\hline Technical & $725^{b}$ & 8 & 530 & 15.7 & 73.4 & 20.8 & 1328 & 10.4 \\
\hline University & $562^{\mathrm{b}}$ & 6.2 & 697 & 20.7 & 174.4 & 49.3 & 1433 & 11.2 \\
\hline Total N & 9083 & 100 & 3368 & 100 & 353.4 & 100 & 12805 & 100 \\
\hline Horizontal percentage & 70.9 & & 26.3 & & 2.8 & & 100 & \\
\hline \multicolumn{9}{|l|}{ Years of education } \\
\hline Mean & 6.9 & & 10.8 & & 13.7 & & 8.2 & \\
\hline Median & 5 & & 11 & & 14 & & 9 & \\
\hline
\end{tabular}

Source: prepared by the author on the basis of the 2003 National Household Survey (ENAHO).

a Population aged 25 or over (sample expansion).

b Small number of observations, $10 \%$ or less of the social group. 
and despite the expansion of the education system, indigenous populations in Peru still suffer a significant degree of exclusion from the education system, both quantitatively and qualitatively.

\section{H2. Hypothesis of "separability" and hierarchy in the relationship between education and income}

The static sigma model predicts a positive relationship between mean years of education and mean incomes, but this relationship is separable and hierarchical by social group in ascending order Z, Y, A. This is precisely what the reduced form of the model claims, as shown in equation (3) and figure 1 . Using the reducedform equation to test the sigma model therefore has epistemological justification; there is no need to test it via the structural equations. In other words, if equation (3) were false, the assumptions contained in equations (1) and (2) could not be true.

Table 3 presents data on incomes by education level and social group. In this case, population refers to the economically active population (EAP) who are employed (the small unemployed group is not considered). The observed data suggest the existence of a direct relationship between mean income and education level both within social groups and between them. The question is whether the observed relationships are statistically separable for each social group and whether they display an A, Y, Z hierarchy as the hypothesis proposes.

Given the existence of quantitative educational exclusion, corroborating hypothesis $H 1$, some cells in table 3 contain very small numbers. The test must then be carried out only between comparable levels of education. The members of group $\mathrm{Z}$ are concentrated in the initial education levels; only a small fraction, less than $10 \%$, reach post-secondary levels. In group $\mathrm{Y}$, there is a small illiterate population. In group A, no one was illiterate or had primary education only. The comparable or relevant levels of education and social groups are thus the following: at primary level, groups Y and Z; at secondary level, all three groups $\mathrm{A}, \mathrm{Y}$ and $\mathrm{Z}$; and at the technical and university levels, groups A and Y. The results of the statistical tests contained in the Appendix show that the observed differences are generally significant. In short, the empirical data do not refute hypothesis $H 2$.

TABLE 3

Peru: mean income by education level and social group, 2003

(Thousands of people, soles per month and percentages)

\begin{tabular}{|c|c|c|c|c|c|c|c|c|c|}
\hline \multirow{3}{*}{ Education level } & \multicolumn{6}{|c|}{ Social group } & \multirow{2}{*}{\multicolumn{3}{|c|}{ Total }} \\
\hline & \multicolumn{2}{|l|}{$\mathrm{Z}$} & \multicolumn{2}{|l|}{$\mathrm{Y}$} & \multicolumn{2}{|l|}{ A } & & & \\
\hline & $\begin{array}{c}\mathrm{N}^{\mathrm{a}} \\
\text { (percentage) }\end{array}$ & $\mathrm{y}^{\mathrm{b}}$ & $\begin{array}{c}\mathrm{N} \\
\text { (percentage) }\end{array}$ & $\mathrm{y}$ & $\begin{array}{c}\mathrm{N} \\
\text { (percentage) }\end{array}$ & $\mathrm{y}$ & $\mathrm{N}$ & (percentage) & $\mathrm{y}$ \\
\hline None & $9.6^{\mathrm{c}}$ & 171 & $1.9^{\mathrm{c}}$ & 297 & - & - & 604 & 7.1 & 180 \\
\hline Basic & 41 & 330 & 13.1 & 479 & $1.0^{\mathrm{c}}$ & 137 & 2704 & 32 & 346 \\
\hline Secondary & 32.7 & 592 & 44 & 710 & 22.7 & 798 & 2998 & 35.4 & 637 \\
\hline Technical & $9.6^{\mathrm{c}}$ & 844 & 17.2 & 912 & 15.8 & 965 & 1001 & 11.9 & 876 \\
\hline University & $7.1^{\mathrm{c}}$ & 1529 & 23.8 & 2005 & 60.5 & 2721 & 1148 & 13.6 & 1943 \\
\hline Total & 100 & 535 & 100 & 1015 & 100 & 1981 & 8464 & 100 & 717 \\
\hline Total N & 5841 & & 2330 & & 293 & & 8464 & & \\
\hline Horizontal percentage & 69 & & 27.5 & & 3.5 & & 100 & & \\
\hline \multicolumn{10}{|l|}{ Years of education } \\
\hline Mean & 7.6 & & 11.4 & & 14.2 & & 9 & & \\
\hline Median & 8 & & 11 & & 15 & & 11 & & \\
\hline
\end{tabular}

Source: prepared by the author on the basis of the 2003 National Household Survey (ENAHO).

a Population aged 25 or over (sample expansion).

b Mean income in soles, Lima, October 2003.

c Small number of observations, $10 \%$ or less of the social group.

- No population exists in this category. 
Figure 2 illustrates the nature of the empirical relationship found between income and education, showing the relevant levels for comparison. The gradients of the lines shown suggest a rising trend in the three social groups. Moreover, the slope of curve $\mathrm{A}$ rises faster than that of $\mathrm{Y}$, and that of $\mathrm{Y}$ more rapidly than that of curve $\mathrm{Z}$.

The standard regression method could be applied to these data to test the relationships between the slopes econometrically, using social groups A, Y and $\mathrm{Z}$ as dummy variables. However, the data reveal secondary education as the only relevant level for comparison. As is well known, an implicit assumption of the standard regression model is that dummy variables must cover the entire range of observations of the independent variables; if exclusion exists in the distribution of the regressors, as in the case shown in figure 2 , the standard regression model is not applicable. In fact, standard econometric theory implicitly assumes the absence of exclusions in the relationships between variables.

FIGURE 2

Peru: Empirical relationship between mean income (y) and education level, by ethnic group

Mean income

(soles per month)

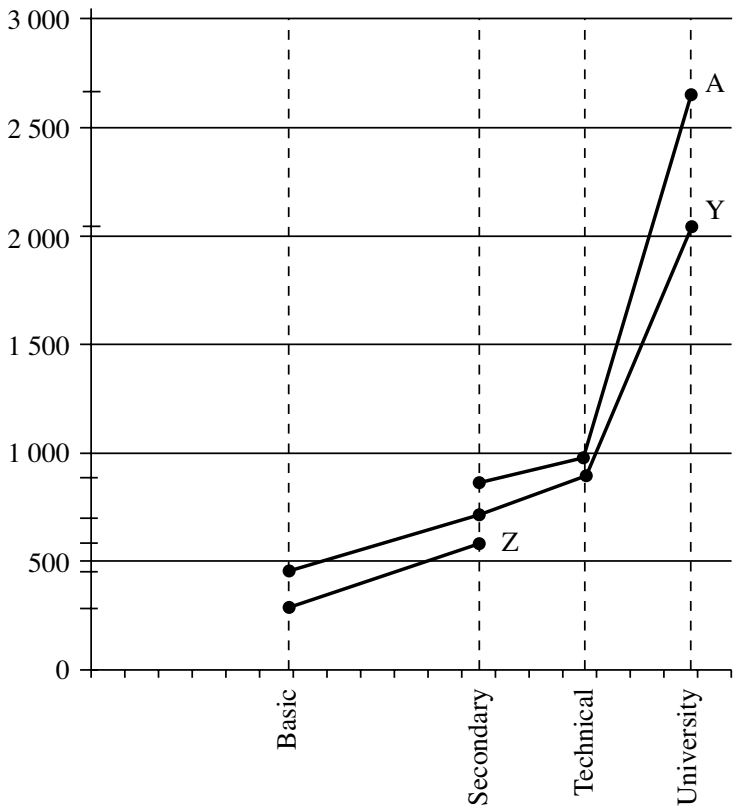

Education level

Source: prepared by the author on the basis of table 2 data.

\section{H3. Hypothesis of "separability" and hierarchy in the relationships between education and wages}

If wages are substituted for income on the vertical axis, figure 1 can also represent the relationships between education and wages. A number of assumptions will be introduced here. First, labour productivity depends upon the level of workers' human capital, not on their education level. Second, profit-maximizing firms operating in competitive labour markets will hire workers according to their labour productivity and will pay uniform wages for a given level of human capital.

The static labour-market equilibrium situation can be written as follows:

$$
\begin{gathered}
k_{h}=f(E, X), f_{1}>0, f_{2}>0 \\
w=h\left(K_{h}, X, p\right), h_{1}>0, h_{2}>0, h_{3}>0
\end{gathered}
$$

Hence,

$$
\begin{gathered}
w=h(f(E, X), X, p)=H(E, X, p), \\
H_{1}>0, H_{2}>0, H_{3}>0
\end{gathered}
$$

Equation (4) is the old equation (1) showing the transformation of education into human capital. Equation (5) is also an old friend, now showing the transformation of human capital into wages $(w)$. Equation (6) is the reduced-form equation, now showing that wages ultimately depend upon education and social group, for a given value of $p$.

Tables 4A and 4B present data on education and pay in blue-collar and white-collar labour markets, respectively. The mean white-collar salary is twice the mean blue-collar wage. The difference in education goes in the same direction: mean years of schooling is 13.7 years for white-collar workers and 8.5 for blue-collar workers, with median values of 14 and 10 respectively. Education levels appear as a factor differentiating the two social groups. The proportion of $\mathrm{Z}$ workers engaged in the blue-collar labour market is $20 \%$, but the figure for the white-collar market is only $14 \%$. Within group $\mathrm{Y}$, the equivalent proportions are $21 \%$ and $36 \%$, while in group A they are $8 \%$ and $62 \%$.

The relevant education levels for comparison among blue-collar workers (see table 4A) include basic and secondary, while the workers concerned are those from the $\mathrm{Y}$ and $\mathrm{Z}$ groups. In each case, the 


\begin{tabular}{|c|c|c|c|c|c|c|c|c|}
\hline \multirow{3}{*}{ Education level } & \multicolumn{6}{|c|}{ Social group } & \multirow{2}{*}{\multicolumn{2}{|c|}{ Total }} \\
\hline & \multicolumn{2}{|c|}{$\mathrm{Z}$} & \multicolumn{2}{|c|}{$\mathrm{Y}$} & \multicolumn{2}{|c|}{ A } & & \\
\hline & $\mathrm{N}^{\mathrm{a}}(\%)$ & $M W^{b}$ & $\mathrm{~N}(\%)$ & $M w^{b}$ & $\mathrm{~N}(\%)$ & $M W^{b}$ & $\mathrm{~N}(\%)$ & $\mathrm{MW}^{\mathrm{b}}$ \\
\hline None & $6^{\mathrm{c}}$ & 306 & $1.8^{\mathrm{c}}$ & 349 & - & - & 4.7 & 310 \\
\hline Basic & 37.5 & 489 & 21.6 & 518 & - & - & 32.4 & 490 \\
\hline Secondary & 46.7 & 616 & 59.4 & 651 & 78.2 & 569 & 50.8 & 627 \\
\hline Technical & $8.1^{\mathrm{c}}$ & 695 & 13.8 & 712 & 21.8 & 743 & 10 & 703 \\
\hline University & $1.7^{\mathrm{c}}$ & 763 & $3.4^{\mathrm{c}}$ & 796 & - & - & 2.1 & 778 \\
\hline Total & \multicolumn{2}{|l|}{100} & \multicolumn{2}{|l|}{100} & 100 & 606 & 100 & 579 \\
\hline Total N & \multirow{2}{*}{\multicolumn{2}{|c|}{$\begin{array}{rr}1163 \\
\quad 69.7\end{array}$}} & \multirow{2}{*}{\multicolumn{2}{|c|}{$\begin{array}{c}482 \\
28.9\end{array}$}} & \multirow{2}{*}{\multicolumn{2}{|c|}{$\begin{array}{l}23 \\
1.4\end{array}$}} & \multirow{2}{*}{\multicolumn{2}{|c|}{$\begin{array}{r}1668 \\
100\end{array}$}} \\
\hline Horizontal percentage & & & & & & & & \\
\hline Percentage of total EAP (from table 3) & \multicolumn{2}{|l|}{19.9} & \multicolumn{2}{|l|}{20.7} & \multicolumn{2}{|l|}{7.8} & \multicolumn{2}{|l|}{19.7} \\
\hline \multicolumn{9}{|l|}{ Years of education } \\
\hline Mean & \multicolumn{2}{|l|}{8} & \multicolumn{2}{|l|}{9.7} & \multicolumn{2}{|l|}{11.3} & \multicolumn{2}{|l|}{8.6} \\
\hline Median & \multicolumn{2}{|l|}{9} & \multicolumn{2}{|l|}{11} & \multicolumn{2}{|l|}{11} & \multicolumn{2}{|l|}{10} \\
\hline
\end{tabular}

Source: prepared by the author on the basis of the 2003 National Household Survey (ENAHO).

a Population of blue-collar workers aged 25 or over (sample expansion).

b Mean wage in soles, Lima, October 2003.

c Small number of observations, $10 \%$ or less of the social group.

EAP Economically active population.

- No population exists in this category.

TABLE 4B

Peru: mean salaries (white-collar workers), by education level and social group, 2003 (Thousands of people, soles per month and percentages)

\begin{tabular}{|c|c|c|c|c|c|c|c|c|}
\hline \multirow{3}{*}{ Education level } & \multicolumn{6}{|c|}{ Social group } & \multirow{2}{*}{\multicolumn{2}{|c|}{ Total }} \\
\hline & \multicolumn{2}{|c|}{$\mathrm{Z}$} & \multicolumn{2}{|c|}{$\mathrm{Y}$} & \multicolumn{2}{|c|}{ A } & & \\
\hline & $\mathrm{N}^{\mathrm{a}}(\%)$ & $\mathrm{MS}^{\mathrm{b}}$ & $\mathrm{N}(\%)$ & $\mathrm{MS}^{\mathrm{b}}$ & $\mathrm{N}(\%)$ & $\mathrm{MS}^{\mathrm{b}}$ & $\mathrm{N}(\%)$ & $\mathrm{MS}^{\mathrm{b}}$ \\
\hline $\begin{array}{l}\text { None } \\
\text { Basic } \\
\text { Secondary } \\
\text { Technical } \\
\text { University }\end{array}$ & $\begin{array}{l}0.1^{\mathrm{c}} \\
4.6^{\mathrm{c}} \\
29.2 \\
32.9 \\
33.2\end{array}$ & $\begin{array}{r}357 \\
703 \\
871 \\
1045 \\
1780\end{array}$ & $\begin{array}{l}0.5^{\mathrm{c}} \\
1.8^{\mathrm{c}} \\
28.1 \\
26.2 \\
43.4\end{array}$ & $\begin{array}{r}431 \\
641 \\
707 \\
1009 \\
2203\end{array}$ & $\begin{array}{c}- \\
\overline{-} \\
14.2 \\
17.7 \\
68.1\end{array}$ & $\begin{array}{rrr} & - \\
& - \\
& 763 \\
1 & 102 \\
3 & 182\end{array}$ & $\begin{array}{r}0.3 \\
2.8 \\
27.2 \\
28.4 \\
41.3\end{array}$ & $\begin{array}{r}415 \\
685 \\
788 \\
1033 \\
2212\end{array}$ \\
\hline Total & 100 & 1222 & 100 & 1433 & 100 & 2469 & 100 & 1442 \\
\hline $\begin{array}{l}\text { Total N } \\
\text { Horizontal percentage }\end{array}$ & $\begin{array}{c}807 \\
44.3 \\
\end{array}$ & & $\begin{array}{l}833 \\
45.7 \\
\end{array}$ & & $\begin{array}{r}181 \\
10 \\
\end{array}$ & & $\begin{array}{r}1821 \\
100 \\
\end{array}$ & \\
\hline Percentage of total EAP (from table 3) & 13.8 & & 35.7 & & 61.8 & & 21.5 & \\
\hline $\begin{array}{l}\text { Years of education } \\
\text { Mean } \\
\text { Median }\end{array}$ & $\begin{array}{l}13.5 \\
14\end{array}$ & & $\begin{array}{l}13.7 \\
14\end{array}$ & & $\begin{array}{l}14.9 \\
16\end{array}$ & & $\begin{array}{l}13.7 \\
14\end{array}$ & \\
\hline
\end{tabular}

Source: prepared by the author on the basis of the 2003 National Household Survey (ENAHO).

Population of white-collar workers aged 25 or over (sample expansion).

Mean salary in soles, Lima, October 2003.

Small number of observations, $10 \%$ or less of the social group.

EAP Economically active population.

- No population exists in this category. 
observed average wage of $\mathrm{Y}$ workers is higher than that of $\mathrm{Z}$ workers. The statistical test shows that these differences are statistically significant at the secondary education level only (which represents the largest group in this labour market), as shown in the Appendix. The relevant education levels for comparison among white-collar workers (see table 4B) include the secondary, technical and university levels and the Z, Y and A social groups. The statistical test shows that the differences are statistically significant in five of the nine cases, and at the university level the difference is consistently significant, as shown in the Appendix.

Overall, the empirical evidence presented here shows that wages and salaries depend positively on workers' education level. As white-collar workers tend to have more education than blue-collar workers, the mean salary of the former is higher than the mean wage of the latter. Lastly, for a given and relevant level of education, pay in general depends on the social group hierarchy, given by the order A, Y, Z. The same relationship is observed in the case of white-collar salaries. In brief, the empirical data presented do not refute hypothesis $H 3$.

\section{H4. Hypothesis of the gap necessarily existing between wage and own-account income}

How is labour discipline secured at the firm level in a sigma society? As stated in section II, sigma theory assumes that firms face conflict in their labour relations, so employers must find ways to extract effort from workers. Accordingly, they will seek to pay a market wage rate above the opportunity cost to the workers hired, so workers found shirking will be fired and will then suffer an economic cost, represented by this wage premium. The opportunity cost for hired workers will be equal to the income they can make in own-account (self-employed) activities. This differential is the labour discipline device used by capitalist enterprises to secure the highest level of labour productivity in overpopulated societies. For a given level of human capital, the sigma model thus predicts a gap between the price paid for labour services in the labour market (wages or salaries) and own-account incomes.

Suppose the equilibrium situation implies a $30 \%$ gap between wages and own-account income. As the average wage of social group $\mathrm{Y}$ is higher than the average wage of social group $\mathrm{Z}$ (shown in $\mathrm{H} 3$ above), the own-account incomes of these social groups must follow the same ranking. The efficiency gap applies to each social group separately. This hypothesis differs from the standard Lewis model (Lewis, 1954), which ignores the ethnicity factor so that the efficiency gap is uniform for all workers.

Table 5 presents data on the mean incomes of wage earners, salary earners and own-account workers, separated by social group. In social group Z, aggregate own-account income is lower than salaries and wages.

TABLE 5

Peru: mean wage, mean salary and mean own-account income, by social group, 2003 (Soles per month)

\begin{tabular}{|c|c|c|c|c|c|c|}
\hline \multirow{2}{*}{ Social group } & \multicolumn{5}{|c|}{ Education level } & \multirow{2}{*}{ Total } \\
\hline & None & Basic & Secondary & Technical & University & \\
\hline \multicolumn{7}{|c|}{ Group Z } \\
\hline Salary & $357^{\mathrm{a}}$ & $703^{\mathrm{a}}$ & $871^{\mathrm{a}}$ & $1045^{\mathrm{a}}$ & $1780^{\mathrm{a}}$ & 1222 \\
\hline Wage & $306^{\mathrm{a}}$ & 483 & 618 & $695^{\mathrm{a}}$ & $763^{\mathrm{a}}$ & 557 \\
\hline Own-account income & 136 & 260 & 451 & $568^{\mathrm{a}}$ & $818^{\mathrm{a}}$ & 327 \\
\hline \multicolumn{7}{|c|}{ Group Y } \\
\hline Salary & $431^{\mathrm{a}}$ & $641^{\mathrm{a}}$ & 707 & 1009 & 2203 & 1433 \\
\hline Wage & $349^{\mathrm{a}}$ & $518^{\mathrm{a}}$ & 651 & $712^{\mathrm{a}}$ & $796^{\mathrm{a}}$ & 630 \\
\hline Own-account income & $221^{\mathrm{a}}$ & $384^{\mathrm{a}}$ & 550 & 696 & 1180 & 621 \\
\hline \multicolumn{7}{|c|}{ Group A } \\
\hline Salary & - & - & 763 & 1102 & 3182 & 2469 \\
\hline Wage & - & - & $568^{\mathrm{a}}$ & $743^{\mathrm{a}}$ & & 608 \\
\hline Own-account income & - & $137^{\mathrm{a}}$ & 1032 & $508^{a}$ & 1135 & 1013 \\
\hline
\end{tabular}

Source: prepared by the author on the basis of the 2003 National Household Survey (ENAHO).

a Small number of observations, $10 \%$ or less of the social group.

- No population exists in this category. 
This relationship also holds true for the relevant education levels. Table 5 shows similar relationships for social group Y, but in group A the relationships seem less clear than in the other social groups. At the relevant education level, which is university, the relationship is fairly clear, however. The observed differences are all statistically significant, as shown in the Appendix, so the empirical data do not refute the model.

Figure 3 summarizes the results. In group Z, the average wage is higher than average own-account income at both the basic and secondary education levels, which are the relevant comparison categories. In group $\mathrm{Y}$, the average salary is higher than average own-account income at the three relevant education levels: secondary, technical and university.

To summarize, Peru's labour markets seem to operate as predicted by the sigma model, so that the self-employed are mostly underemployed and hence form part of the excess labour supply: they would prefer employment in the labour market at current wage or salary rates.

Table 6 shows data on excess labour supply (unemployment and underemployment) by social

FIGURE 3

Peru: empirical relationship between wages or salaries and own-account income, by ethnic group

Mean income (soles per month)

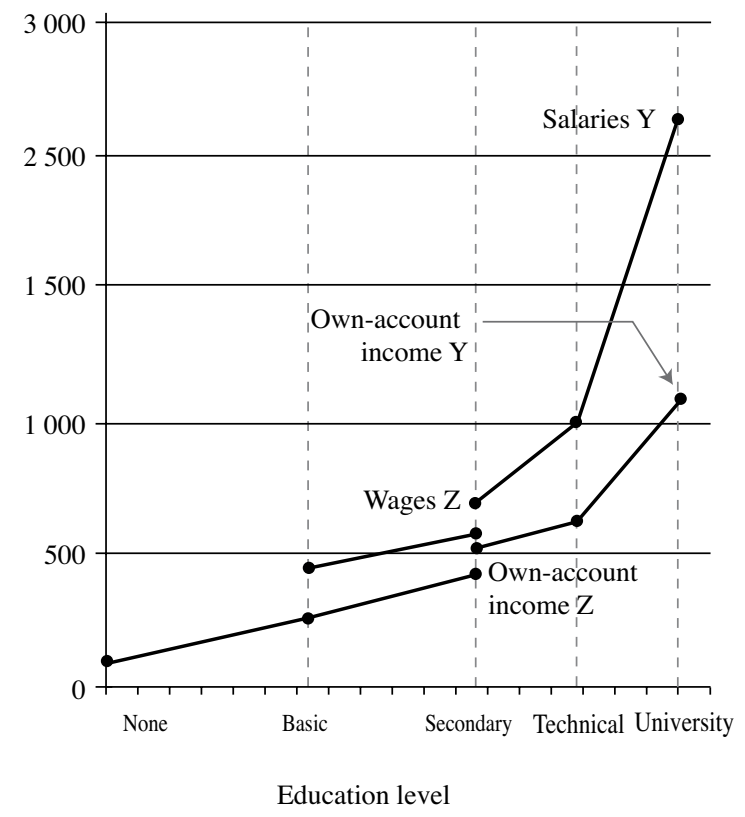

Source: prepared by the author on the basis of table 4 data. group. In terms of differences between social groups, the results indicate very high rates of excess labour supply: $66 \%$ in social group Z, $45 \%$ in social group $\mathrm{Y}$ and $32 \%$ in social group $\mathrm{A}$. The Appendix shows that the observed differences in the rate of excess supply by education level and social group, in the relevant categories, are statistically significant. As unemployment rates do not differ greatly, this difference mainly reflects rates of underemployment.

\section{H5. Hypothesis of high education mobility but low income mobility}

The dynamic sigma model predicts that mean years of education tend to equalize between social groups over time, but mean incomes do not. This prediction can be tested statistically using age brackets as indicators of intergenerational differences.

Tables 7A and 7B present ratios of education and incomes for intergenerational groups of workers and social groups, respectively. Table 7A shows a large

TABLE 6

Peru: rate of excess labour supply (unemployment and underemployment), by education level and social group, 2003 (Percentages)

\begin{tabular}{lcccc}
\hline \multirow{2}{*}{ Education level } & \multicolumn{3}{c}{ Social group } & \\
\cline { 2 - 4 } & $\mathrm{Z}$ & $\mathrm{Y}$ & $\mathrm{A}$ & Total \\
\cline { 2 - 4 } None & 88.1 & $73.7^{\mathrm{a}}$ & - & 87.1 \\
& $(11.7)^{b}$ & $(12.3)$ & & $(11.7)$ \\
Basic & & & & \\
& 79.7 & 61.8 & $100.0^{\mathrm{a}}$ & 77.7 \\
Secondary & $(6.5)$ & $(7.2)$ & 0.0 & $(6.6)$ \\
& 57.6 & 49.8 & 39.3 & 54.4 \\
Technical & $(5.4)$ & $(8.2)$ & $(11.4)$ & $(6.5)$ \\
& $35.0^{\mathrm{a}}$ & 31.1 & 25.7 & 32.9 \\
University & $(5.6)$ & $(7.3)$ & $(12.4)$ & $(6.6)$ \\
& $29.3^{\mathrm{a}}$ & 32.7 & 28.8 & 31.0 \\
Total & $(7.0)$ & $(8.7)$ & $(2.7)$ & $(7.2)$ \\
& 65.6 & 44.5 & 31.5 & 58.4 \\
& $(6.6)$ & $(8.1)$ & $(6.4)$ & $(7.0)$ \\
\hline
\end{tabular}

Source: prepared by the author on the basis of the 2003 National Household Survey (ENAHO).

a Small number of observations, $10 \%$ or less of the social group.

b Unemployment rate in parenthesis; underemployment is therefore the difference between the total rate of excess labour supply (shown in the table) and the unemployment rate (in parenthesis).

- No population exists in this category. 
TABLE 7A

Peru: mean years of schooling by age bracket and social group, 2003

\begin{tabular}{|c|c|c|c|c|c|c|c|c|c|c|}
\hline \multirow{3}{*}{ Social group } & \multicolumn{8}{|c|}{ Age bracket (years) } & \multirow{2}{*}{\multicolumn{2}{|c|}{ Total }} \\
\hline & \multicolumn{2}{|c|}{$25-34$} & \multicolumn{2}{|c|}{$35-44$} & \multicolumn{2}{|c|}{$45-54$} & \multicolumn{2}{|c|}{$55-65$} & & \\
\hline & $\mathrm{N}^{\mathrm{a}}$ & $E^{b}$ & $\mathrm{~N}$ & $\mathrm{E}$ & $\mathrm{N}$ & $\mathrm{E}$ & $\mathrm{N}$ & $\mathrm{E}$ & $\mathrm{N}$ & $\mathrm{E}$ \\
\hline Z & 1551 & 11 & 1636 & 8 & 1260 & 7 & 850 & 5 & 5297 & 8 \\
\hline $\mathrm{Y}$ & 912 & 12 & 670 & 12 & 449 & 11 & 218 & 9 & 2249 & 12 \\
\hline A & 146 & 14 & 111 & 14 & 29 & 14 & 6 & 12 & 291 & 14 \\
\hline Total & 2609 & 12 & 2417 & 10 & 1738 & 8 & 1074 & 6 & 7837 & 9 \\
\hline Ratio Z/A & \multicolumn{2}{|c|}{0.8} & \multicolumn{2}{|c|}{0.6} & \multicolumn{2}{|c|}{0.5} & \multicolumn{2}{|c|}{0.4} & \multicolumn{2}{|c|}{0.6} \\
\hline Ratio Y/A & \multicolumn{2}{|c|}{0.9} & \multicolumn{2}{|c|}{0.8} & \multicolumn{2}{|c|}{0.8} & \multicolumn{2}{|c|}{0.7} & \multicolumn{2}{|c|}{1.2} \\
\hline
\end{tabular}

Source: prepared by the author on the basis of the 2003 National Household Survey (ENAHO).

a Employed economically active population (thousands of people).

b Mean years of schooling.

TABLE 7B

Peru: mean income by age bracket and social group, 2003

\begin{tabular}{|c|c|c|c|c|c|c|c|c|c|c|}
\hline \multirow{3}{*}{ Social group } & \multicolumn{8}{|c|}{ Age bracket (years) } & \multirow{2}{*}{\multicolumn{2}{|c|}{ Total }} \\
\hline & \multicolumn{2}{|c|}{$25-34$} & \multicolumn{2}{|c|}{$35-44$} & \multicolumn{2}{|c|}{$45-54$} & \multicolumn{2}{|c|}{$55-65$} & & \\
\hline & $\mathrm{N}^{\mathrm{a}}$ & $y^{b}$ & $\mathrm{~N}$ & $\mathrm{y}$ & $\mathrm{N}$ & $\mathrm{y}$ & $\mathrm{N}$ & $\mathrm{y}$ & $\mathrm{N}$ & $\mathrm{y}$ \\
\hline $\mathrm{Z}$ & 1551 & 530 & 1636 & 596 & 1260 & 623 & 850 & 473 & 5297 & 563 \\
\hline $\mathrm{Y}$ & 912 & 771 & 670 & 987 & 449 & 1195 & 218 & 1626 & 2249 & 1003 \\
\hline A & 146 & 1456 & 111 & 2455 & 29 & 2982 & 6 & 1648 & 291 & 1991 \\
\hline Total & 2609 & 666 & 2417 & 790 & 1738 & 810 & 1074 & 713 & 7837 & 743 \\
\hline Ratio Z/A & \multicolumn{2}{|c|}{0.4} & \multicolumn{2}{|c|}{0.2} & \multicolumn{2}{|c|}{0.2} & \multicolumn{2}{|c|}{0.3} & \multicolumn{2}{|c|}{0.3} \\
\hline Ratio Y/A & \multicolumn{2}{|c|}{0.5} & \multicolumn{2}{|c|}{0.4} & \multicolumn{2}{|c|}{0.4} & \multicolumn{2}{|c|}{1.0} & \multicolumn{2}{|c|}{0.5} \\
\hline
\end{tabular}

Source: prepared by the author on the basis of the 2003 National Household Survey (ENAHO).

a Employed economically active population (thousands of people).

b Mean income (soles per month).

increase in years of schooling between generations in social group Z: the "children" (in the social, not the biological sense) have twice as many years of schooling as the "parents", although the increase generated in other social groups is smaller. In social group A, education appears to come up against a ceiling at around 14 years. As a result, the educational gaps between group $\mathrm{Z}$ and the other groups have narrowed considerably.

The estimated changes in income gaps across generations are shown in table 7B. The mean income of social group $\mathrm{Z}$ in relation to social group $\mathrm{A}$ has not changed much: the relative income of the "parents" is $30 \%$ and that of the "children" is $40 \%$, which is small compared to the changes in educational attainment shown in table 7A. The situation of social group Y relative to group A shows a similar pattern. The relative income of the "parents" and "children" is almost constant at around $40 \%$ and $50 \%$, except for the eldest group, in which the figure is $100 \%$. The latter result is certainly a paradox, possibly due to the small size of this group. 
The conclusion regarding the convergence trends between social groups of different generations is that, while there is a tendency for differences in years of schooling to narrow, there is no similar trend towards lower income inequality. This empirical result is consistent with the hypothesis.

Regarding the degree of income inequality in Peru, the Gini coefficient estimated from the ENAHO 2003 dataset is 0.59 , which is close to other estimates made in the past $(0.60)$, based on national accounts. This figure must underestimate the true Gini coefficient because the incomes of Peru's economic élite are not included in the sample. It is well known that economic élites are absent or underrepresented in household sample surveys. Strictly speaking,

\section{VII}

\section{Conclusions}

The sigma model constructed in this paper predicts a set of empirically falsifiable hypotheses for the relationships between education and income. When compared against the Peruvian data, the statistical tests show that the hypotheses are not rejected. The sigma model also predicts the paradox observed in developing countries, in which a significant increase in the number of years of education has not been accompanied by less income inequality.

The conclusion that education is not an incomeequalizing system is explained by two factors: the the empirical social group A mostly consists of the middle class (executives, administrators and top professionals) and does not correspond to the capitalist class of the model. Theoretically, in the dual social structure of capitalists and workers, the middle class is usually included in the capitalist category (Wright, 1997). This is also the criterion followed in this study.

Peru still displays a relatively high degree of inequality and remains one of the most unequal countries in the world. As the sigma model predicts, education does not seem to be an income-equalizing system. Even if people have the same number of schooling years, average incomes will still depend on the social group to which they belong. initial inequality in the distribution of economic and political assets between social groups (high degree of inequality) and society's factor endowments (overpopulation). Initial inequality and overpopulation are the ultimate factors explaining the paradox; in other words, they are the exogenous variables of the sigma model. Thus, as long as these exogenous variables remain unchanged, the education system will remain non-equalizing.

(Original: English) 
APPENDIX

Summary of statistical tests

Hypothesis 1: Differences in mean years of schooling

\begin{tabular}{|c|c|c|c|c|c|c|c|}
\hline \multirow{2}{*}{ Social groups } & \multicolumn{2}{|c|}{ Variance equality test } & \multicolumn{5}{|c|}{ Difference of means test } \\
\hline & T-statistics & $p$ value & Difference & Confide & nterval & $\mathrm{F}$ & $p$ value \\
\hline$Z-Y$ & 354.56 & 0.00 & -3.96 & {$[-4.10$} & $-3.81]$ & 2024.4 & 0 \\
\hline $\mathrm{Z}-\mathrm{A}$ & 150.21 & 0.00 & -6.87 & {$[-7.20$} & $-6.55]$ & 1620.48 & 0 \\
\hline$Y-A$ & 53.21 & 0.00 & -2.92 & {$[-3.26$} & $-2.58]$ & 258.3 & 0 \\
\hline
\end{tabular}

Mann-Whitney U-test

\begin{tabular}{|c|c|c|c|c|}
\hline \multirow{2}{*}{ Social groups } & \multicolumn{2}{|c|}{ Sum of ranks } & \multirow{2}{*}{ Z-statistics } & \multirow{2}{*}{$p$ value } \\
\hline & $\mathrm{Z}$ & $\mathrm{Y}$ & & \\
\hline$Z-Y$ & 490300000 & 218000000 & -61.49 & 0.00 \\
\hline $\mathrm{Z}-\mathrm{A}$ & 420400000 & 10058291 & -24.62 & 0.00 \\
\hline $\mathrm{Y}-\mathrm{A}$ & 38984586 & 2479585 & -12.57 & 0.00 \\
\hline
\end{tabular}

Source: prepared by the author.

Statistical testing relates to the differences in mean years of schooling between social groups. The first test uses F-statistics and the second the (non-parametric) Mann-Whitney U-test. The results show that the observed mean differences are statistically significant.

Hypothesis 2: Mean income differences

\begin{tabular}{|c|c|c|c|c|c|c|c|c|}
\hline \multirow{3}{*}{$\begin{array}{l}\text { Level of } \\
\text { education }\end{array}$} & \multirow{3}{*}{$\begin{array}{c}\begin{array}{c}\text { Social } \\
\text { groups }\end{array} \\
\mathrm{Z}-\mathrm{Y}\end{array}$} & \multicolumn{2}{|c|}{ Variance equality test } & \multicolumn{5}{|c|}{ Difference of means test } \\
\hline & & \multirow{2}{*}{$\frac{\text { T-statistics }}{4.24}$} & \multirow{2}{*}{$\frac{p \text { value }}{0.04}$} & \multirow{2}{*}{$\begin{array}{c}\text { Difference } \\
-126.41\end{array}$} & \multicolumn{2}{|c|}{ Confidence interval } & \multirow{2}{*}{$\frac{\text { F-statistics }}{33.04}$} & \multirow{2}{*}{$\frac{p \text { value }}{0.00}$} \\
\hline & & & & & {$[-164.86$} & $-87.97]$ & & \\
\hline Secondary & $\begin{array}{l}Z-Y \\
Z-A \\
Y-A\end{array}$ & $\begin{array}{l}0.63 \\
0.15 \\
0.07\end{array}$ & $\begin{array}{l}0.43 \\
0.70 \\
0.80\end{array}$ & $\begin{array}{l}-102.02 \\
-217.56 \\
-115.54\end{array}$ & $\begin{array}{l}{[-162.35} \\
{[-513.60} \\
{[-416.41}\end{array}$ & $\begin{array}{r}-41.68] \\
78.47] \\
185.32]\end{array}$ & $\begin{array}{l}6.35 \\
2.11 \\
0.35\end{array}$ & $\begin{array}{l}0.01 \\
0.15 \\
0.55\end{array}$ \\
\hline Technical & $\mathrm{Y}-\mathrm{A}$ & 0.96 & 0.33 & -41.85 & {$[-307.86$} & 224.17] & 0.15 & 0.69 \\
\hline University & $\mathrm{Y}-\mathrm{A}$ & 21.48 & 0.00 & -938.12 & {$[-1677.40$} & $-198.83]$ & 3.30 & 0.07 \\
\hline
\end{tabular}

\begin{tabular}{|c|c|c|c|c|c|}
\hline \multirow{3}{*}{ Level of education } & \multirow{3}{*}{ Social groups } & \multicolumn{4}{|c|}{ Mann-Whitney U-test } \\
\hline & & \multicolumn{2}{|c|}{ Sum of ranks } & \multirow{2}{*}{ Z-statistics } & \multirow{2}{*}{$p$ value } \\
\hline & & $\mathrm{Z}$ & $\mathrm{Y}$ & & \\
\hline Basic & $\mathrm{Z}-\mathrm{Y}$ & 34224589 & 4808441 & -9.83 & 0.00 \\
\hline Secondary & $\begin{array}{l}Z-Y \\
Z-A \\
Y-A\end{array}$ & $\begin{array}{r}23098507 \\
17017958 \\
3033103\end{array}$ & $\begin{array}{r}10714470 \\
289828 \\
113184\end{array}$ & $\begin{array}{l}-7.61 \\
-2.76 \\
-1.20\end{array}$ & $\begin{array}{l}0.00 \\
0.01 \\
0.23\end{array}$ \\
\hline Technical & $\mathrm{Y}-\mathrm{A}$ & 553451 & 31370 & -0.72 & 0.47 \\
\hline University & $\mathrm{Y}-\mathrm{A}$ & 785177 & 103934 & -0.66 & 0.00 \\
\hline
\end{tabular}

Source: prepared by the author. 
The test now relates to mean income differences between social groups. The parametric and nonparametric tests show that the observed differences are statistically significant at the basic and university levels of education. For the other levels of education, the parametric test does not pass the test of variance equality; hence, parametric tests are the relevant ones. These show that differences are not statistically significant at the technical level, whereas at the secondary level the differences are significant in all groups except Y-A. In four out of six cases, the hypothesis is not refuted by the facts.

Hypothesis 3: Differences in mean salaries and mean wages

White-collar workers: salaries

\begin{tabular}{|c|c|c|c|c|c|c|c|c|}
\hline \multirow{2}{*}{$\begin{array}{l}\text { Level of } \\
\text { education }\end{array}$} & \multirow{2}{*}{$\begin{array}{l}\text { Social } \\
\text { groups }\end{array}$} & \multicolumn{2}{|c|}{ Variance equality test } & \multicolumn{5}{|c|}{ Difference of means test } \\
\hline & & T-statistics & $p$ value & Difference & Confidence & e interval & F-statistics & $p$ value \\
\hline \multirow[t]{3}{*}{ Secondary } & $Z-Y$ & 8.73 & 0.00 & 164.01 & {$[93.99$} & $234.03]$ & 21.08 & 0.00 \\
\hline & $\bar{Z}-\mathrm{A}$ & 1.71 & 0.19 & 107.76 & {$[-143.00$} & $358.52]$ & 0.71 & 0.40 \\
\hline & $\mathrm{Y}-\mathrm{A}$ & 0.39 & 0.53 & -56.25 & {$[-307.71$} & $195.21]$ & 0.19 & 0.66 \\
\hline \multirow[t]{3}{*}{ Technical } & $\mathrm{Z}-\mathrm{Y}$ & 4.75 & 0.03 & 35.85 & {$[-67.13$} & $138.83]$ & 0.47 & 0.50 \\
\hline & $\mathrm{Z}-\mathrm{A}$ & 0.70 & 0.40 & -56.94 & {$[-378.31$} & $264.43]$ & 0.12 & 0.73 \\
\hline & $\mathrm{Y}-\mathrm{A}$ & 0.00 & 0.97 & -92.79 & {$[-421.73$} & $236.15]$ & 0.31 & 0.58 \\
\hline \multirow[t]{3}{*}{ University } & $Z-Y$ & 21.64 & 0.00 & -422.79 & {$\left[\begin{array}{ll}-1 & 011.39\end{array}\right.$} & $165.82]$ & 1.98 & 0.16 \\
\hline & $\mathrm{Z}-\mathrm{A}$ & 60.13 & 0.00 & -1402.16 & {$\left[\begin{array}{ll}-2 & 212.04\end{array}\right.$} & $-592.28]$ & 11.52 & 0.00 \\
\hline & $\mathrm{Y}-\mathrm{A}$ & 16.44 & 0.00 & -979.37 & {$\left[\begin{array}{ll}-1 & 822.26\end{array}\right.$} & $-136.48]$ & 5.19 & 0.02 \\
\hline
\end{tabular}

\begin{tabular}{|c|c|c|c|c|c|}
\hline \multirow{3}{*}{ Level of education } & \multirow{3}{*}{ Social groups } & \multicolumn{4}{|c|}{ Mann-Whitney U-test } \\
\hline & & \multicolumn{2}{|c|}{ Sum of ranks } & \multirow{2}{*}{ Z-statistics } & \multirow{2}{*}{$p$ value } \\
\hline & & $\mathrm{Z}$ & $\mathrm{Y}$ & & \\
\hline Secondary & $\begin{array}{l}Z-Y \\
Z-A \\
Y-A\end{array}$ & $\begin{array}{ll}476 & 879 \\
284 & 144 \\
125 & 362\end{array}$ & $\begin{array}{r}271598 \\
8852 \\
6994\end{array}$ & $\begin{array}{l}4.27 \\
1.63 \\
0.28\end{array}$ & $\begin{array}{l}0.00 \\
0.10 \\
0.78\end{array}$ \\
\hline Technical & $\begin{array}{l}Z-Y \\
Z-A \\
Y-A\end{array}$ & $\begin{array}{l}667938 \\
405470 \\
175 \quad 132\end{array}$ & $\begin{array}{r}391302 \\
13601 \\
10004\end{array}$ & $\begin{array}{l}3.39 \\
1.30 \\
0.35\end{array}$ & $\begin{array}{l}0.00 \\
0.19 \\
0.73\end{array}$ \\
\hline University & $\begin{array}{l}Z-Y \\
Z-A \\
Y-A\end{array}$ & $\begin{array}{l}646406 \\
363848 \\
344454\end{array}$ & 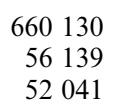 & $\begin{array}{l}-1.85 \\
-5.15 \\
-4.10\end{array}$ & $\begin{array}{l}0.06 \\
0.00 \\
0.00\end{array}$ \\
\hline
\end{tabular}

Source: prepared by the author.

Given the relative size of the social groups (shown in the first hypothesis on exclusion), the relevant comparison is between groups Z-Y-A at the secondary, technical and university levels of education. The contrast for the university level can be made by parametric and non-parametric testing. Owing to the failure in the variance equality test, the other two can be done using non-parametric testing alone. The results show that the observed differences at the university level are consistently statistically significant; in general, the observed values are statistically significant in five of the nine cases. 
Blue-collar workers: wages

\begin{tabular}{|c|c|c|c|c|c|c|c|c|c|}
\hline \multirow{2}{*}{$\begin{array}{l}\text { Level of } \\
\text { education }\end{array}$} & \multirow{2}{*}{$\begin{array}{l}\text { Social } \\
\text { groups }\end{array}$} & \multicolumn{3}{|c|}{ Variance equality test } & \multicolumn{5}{|c|}{ Difference of means test } \\
\hline & & T-statistics & $p$ value & & Difference & Confiden & interval & F-statistics & $p$ value \\
\hline Basic & $\mathrm{Z}-\mathrm{Y}$ & 0.38 & 0.54 & & -35.08 & {$[-115.23$} & 45.07] & 0.74 & 0.39 \\
\hline \multirow[t]{2}{*}{ Secondary } & $Z-Y$ & 4.01 & 0.05 & & -34.34 & {$[-91.07$} & 22.40] & 1.41 & 0.24 \\
\hline & & \multirow{3}{*}{ Social groups } & \multicolumn{7}{|c|}{ Mann-Whitney U-test } \\
\hline \multirow[t]{2}{*}{ Level of education } & & & \multicolumn{4}{|c|}{ Sum of ranks } & \multirow{2}{*}{\multicolumn{2}{|c|}{ Z-statistics }} & \multirow{2}{*}{$p$ value } \\
\hline & & & & $\mathrm{Z}$ & & $\mathrm{Y}$ & & & \\
\hline Basic & & $\mathrm{Z}-\mathrm{Y}$ & & 1139292 & & 212899 & & 0.93 & 0.35 \\
\hline Secondary & & $\mathrm{Z}-\mathrm{Y}$ & & 1653321 & & 774385 & & 2.71 & 0.01 \\
\hline
\end{tabular}

Source: prepared by the author.

The relevant comparison is between groups Z-Y at the basic and secondary levels of education. The parametric test cannot be used because the variance equality test fails. The non-parametric test shows that the observed differences are statistically significant for the secondary education level (the vast majority in the group), but not for the basic level.

Hypothesis 4: Mean differences between wage and salary incomes and own-account incomes

Social group Z

\begin{tabular}{|c|c|c|c|c|c|c|c|}
\hline \multirow[b]{2}{*}{ Level of education } & \multicolumn{2}{|c|}{ Variance equality test } & \multicolumn{5}{|c|}{ Difference of means test } \\
\hline & T-statistics & $p$ value & Difference & Confiden & ce interval & F-statistics & $p$ value \\
\hline Basic & 72.56 & 0.00 & 443.13 & {$[287.90$} & $598.36]$ & 31.31 & 0.00 \\
\hline Secondary & 24.64 & 0.00 & 420.17 & {$[365.23$} & $475.12]$ & 224.64 & 0.00 \\
\hline Total & 495.77 & 0.00 & 894.33 & {$[757.69$} & $1,030.97]$ & 164.58 & 0.00 \\
\hline
\end{tabular}

Mann-Whitney U-test

Level of education

Sum of ranks

\begin{tabular}{lrrrr}
\cline { 2 - 3 } & Own-account & Employed & Z-statistics & $p$ value \\
\hline Basic & 16417007 & 603688 & -11.93 & 0.00 \\
Secondary & 4943900 & 2010686 & -24.30 & 0.00
\end{tabular}


Social group $\mathrm{Y}$

\begin{tabular}{|c|c|c|c|c|c|c|c|}
\hline \multirow[t]{2}{*}{ Level of education } & \multicolumn{2}{|c|}{ Variance equality test } & \multicolumn{5}{|c|}{ Difference of means test } \\
\hline & T-statistics & $p$ value & Difference & \multicolumn{2}{|c|}{ Confidence interval } & F-statistics & $p$ value \\
\hline Secondary & 0.42 & 0.52 & 157.72 & {$[80.83$} & 234.61] & 16.17 & 0.00 \\
\hline Technical & 0.21 & 0.65 & 313.21 & {$[70.70$} & $555.73]$ & 6.41 & 0.01 \\
\hline University & 20.77 & 0.00 & 1022.85 & {$[502.82$} & $1542.88]$ & 14.86 & 0.00 \\
\hline \multirow[t]{2}{*}{ Total } & 140.96 & 0.00 & 812.48 & {$[586.29$} & $1038.68]$ & 49.57 & 0.00 \\
\hline & \multicolumn{7}{|c|}{ Mann-Whitney U-test } \\
\hline \multirow[t]{2}{*}{ Level of education } & \multicolumn{3}{|c|}{ Sum of ranks } & \multirow{2}{*}{\multicolumn{2}{|c|}{ Z-statistics }} & \multirow{2}{*}{\multicolumn{2}{|c|}{$p$ value }} \\
\hline & \multicolumn{2}{|c|}{ Own-account } & Employed & & & & \\
\hline Secondary & \multicolumn{2}{|l|}{772113} & 492733 & \multicolumn{2}{|c|}{-12.58} & \multicolumn{2}{|c|}{0.00} \\
\hline Technical & \multicolumn{2}{|l|}{64839} & 285864 & \multicolumn{2}{|c|}{-13.97} & \multicolumn{2}{|c|}{0.00} \\
\hline University & \multicolumn{2}{|l|}{84954} & 479825 & \multicolumn{2}{|c|}{-12.06} & \multicolumn{2}{|c|}{0.00} \\
\hline
\end{tabular}

In the case of $Z$ workers, the relevant comparisons include the one between the basic and secondary levels of education. Both the parametric and the nonparametric tests show that the observed differences are statistically significant. In the case of $\mathrm{Y}$ workers, the relevant comparisons include the secondary, technical and university levels of education. The nonparametric test shows that the observed differences are statistically significant in all cases. The parametric test is applicable to the university level only, where it also shows that the difference is significant.

Hypothesis 5: Mean differences in labour market exclusion rates

\begin{tabular}{lccc}
\hline Level of education & Social groups & Chi-squared & $p$ value \\
\hline Basic & Z - Y & 6855 & 0.00 \\
Secondary & Z - Y - A & 4855 & 0.00 \\
Technical & Z - Y & 1034 & 0.00 \\
University & Z - Y & 819 & 0.00 \\
\hline
\end{tabular}

Source: prepared by the author.

The chi-squared test is used to test differences in proportions of exclusion from the labour market between social groups. The results show that the observed differences are statistically significant for all levels of education and the relevant social groups at each education level. 


\section{Bibliography}

Akerlof, G. and R. Kranton (2000), "Economics and identity", The Quarterly Journal of Economics, vol. 115, No. 3, Cambridge, Massachusetts, The MIT Press.

Becker, G. and N. Tomes (1979), "An equilibrium theory of the distribution of income and intergenerational mobility", Journal of Political Economy, vol. 87, No. 6, Chicago, University of Chicago Press.

Birdsall, N., A. de la Torre and R. Menezes (2008), Fair Growth: Economic Policies for Latin America's Poor and MiddleIncome Majority, Washington, D.C., Brookings Institution Press.

Blom, A. and C. Vélez (2004), "The dynamics of the skill-premium in Brazil: growing demand and insufficient supply?", Inequality and Economic Development in Brazil, Washington, D.C., World Bank.

Bourguignon, F., F. Ferreira and M. Menendez (2007), "Inequality of opportunity in Brazil", Review of Income and Wealth, vol. 53, No. 4, Oxford, Blackwell Publishing.

Cueto, S., E. Jacoby and E. Pollit (1997), "Rendimiento escolar de niños y niñas en zonas rurales y urbanas del Perú", Revista de psicología, vol. 15, No. 1, Lima, Catholic University of Peru.

Deininger, K. and L. Squire (1996), "A new data set measuring inequality", The World Bank Economic Review, vol. 10, No. 3, Washington, D.C., World Bank.

Durlauf, S. (1996), "A theory of persistent income inequality", Journal of Economic Growth, vol. 1, No. 1, New York, Springer.

Gardner, H. (1999), Intelligence Reframed: Multiple Intelligences for the $21^{\text {st }}$ Century, New York, Basic Books.

Hall, G. and A. Patrinos (2006), Indigenous Peoples, Poverty, and Human Development in Latin America, London, Palgrave.
Hudson, R.A. (1996), Sociolinguistics, Cambridge, Cambridge University Press.

Lewis, A. (1954), "Economic development with unlimited supplies of labor", The Manchester School of Economic and Social Studies, vol. 22, Oxford, Blackwell Publishing.

Li, H., L. Squire and H. Zou (1998), "Explaining international and intertemporal variations in income inequality", The Economic Journal, vol. 108, No. 1, Oxford, Blackwell Publishing.

Marshall, T.H. and T. Bottomore (1992), Citizenship and Social Class, London, Pluto Press.

Mincer, J. (1974), Schooling, Experience, and Earnings, Cambridge, Massachusetts, National Bureau of Economic Research.

Ñopo, H., J. Saavedra and M. Torero (2004), "Ethnicity and earnings in urban Peru", IZA Discussion Papers, No. 980, Bonn, Institute for the Study of Labor (IZA).

Peru, Ministry of Education (2005), Evaluación nacional 2004, Lima.

Ratey, J. (2002), A User's Guide to the Brain, New York, Vintage Books.

Rivera, I. (1979), "Los determinantes de la calidad de la educación en el Perú. Un Estudio ECIEL", Documento de trabajo, No. 44, Lima, Catholic University of Peru.

Rousseau, J. (1984), A Discourse on Inequality, translated from French by Maurice Cranston, New York, Penguin Books. First published in 1755 .

Searle, J. (1995), The Construction of Social Reality, New York, The Free Press.

World Bank (2001), World Development Report. Attacking Poverty, Washington, D.C.

Wright, E. (1997), Class Counts: Comparative Studies in Class Analysis, Cambridge, Cambridge University Press. 